\title{
Characterization of the anhydrosugar content in pyrolysis liquids with column chromatography and iodometric titration
}

K. Meile,

A. Zhurinsh,

G. Dobele

Latvian State Institute of Wood Chemistry,

27 Dzerbenes Street,

Riga LV-1006, Latvia

E-mail: kristine.meile@inbox.lv
Since cellulose and hemicelluloses along with lignin are the main components of biomass, fast pyrolysis of wood yields a complex mixture of products, among which sugars and anhydrosugars are one of the most abundant and valuable components. Because of the presence of high molecular compounds, this sugar mixture of pyrolysis products has proven to be difficult to analyze. In this study, research has been done to improve the characterization of pyrolysis liquids by sample separation on an ion exchange resin. In order to characterize the pyrolysis liquids, an iodometric titration method is used to determine sugar and anhydrosugar content in the pyrolysis liquids with and without sample separation on an ion exchange column.

Key words: ion exchange resins, wood pyrolysis, anhydrosugars, sugars

\section{INTRODUCTION}

With the wasting of fossil resources it is necessary to find new sustainable means for the production of fuels, materials, and chemicals. Wood - one of the most typical examples of biomass - can be processed by hydrolysis or pyrolysis to obtain a vast array of chemical compounds, such as acetic acid [1], methanol [2], various sugars [3], etc. This work is focused on anhydrosugars, mainly 1,6 -anhydro- $\beta$-D-glucopyranose (AGP) and 1,6 -anhydro- $\beta$-D-glucofuranose (AGF), which are the products of fast pyrolysis of wood.

The three main constituents of wood are lignin, cellulose and hemicelluloses, and the total products of wood pyrolysis consist of the pyrolysis products of each of the separate constituents. Pyrolysis is the thermal processing of wood in the absence of molecular oxygen, and according to the pyrolysis conditions there are different types of pyrolysis. Fast pyrolysis is characterized by a rapid increase of temperature, and also a short hot vapor residence time in the reactor. Fast pyrolysis has a characteristically high yield of liquid products - about $75 \%, 12 \%$ gaseous products and $13 \%$ solids or char [4]. The single chemical with the highest yield in pyrolysis liquids is AGP, also known as levoglucosan [5], however, there are also smaller amounts of some other cellulose-derived anhydrosugars present in pyrolysis liquids, such as AGF, cellobiosan, and 1,4:3,6-dianhydro-a-D-glucopyranose [6].

AGF and, especially, AGP have potential uses in the production of polymers, drugs and surfactants [7-8], however, up till now a perfect method for the separation, purification, and determination of the compounds in pyrolysis liquids has not been developed [4].

The presence of AGF can influence the results of the determination of AGP using instrumental 
as well as classical analytical methods. In this study an iodometric titration method is used to determine anhydrosugars in the presence of other sugars. The method is based on the periodate oxidation of carbohydrates. Monosaccharides such as glucose react with 5 moles of sodium periodate [9], AGP reacts with 2 moles of periodate [10] (Fig. 1), while AGF does not react with periodate. The difference between the monosaccharide and anhydrosaccharide stoichiometry allows one to calculate [11] the amount of sugars and AGP or AGF in a sample, if it has been oxidized and titrated both before and after hydrolysis, because anhydrosaccharides are hydrolyzed to the respective monosaccharides by acid hydrolysis at increased temperatures [12].

The iodometric method is fast and easy to perform for routine analysis of AGP and the total sugars, however, the presence of AGF can lead to an inaccurate AGP result, so column chromatography has been used to fractionate the samples of pyrolysis liquids before titration. To perform chromatographic separation of pyrolysis liquids, a weakly acidic cation (WAC) exchange resin was used as the stationary phase and a water / ethanol mixture as the mobile phase [13]. Ion exchange resins belong to the solid organic exchangers. WAC exchange resins have a polyacrylic matrix activated with carboxylic groups [14]. The separation of pyrolysis liquids on an ion exchange column can be influenced by a combination of various retention mechanisms, such as size exclusion, ligand exchange, hydrophobic-hydrophilic interactions, etc. [15].

\section{METHODOLOGY}

\section{Materials and equipment}

All chemicals (analytical grade) were purchased from Sigma-Aldrich and used without further purification. Finex weakly acidic cation exchange resin in the $\mathrm{Na}^{+}$form CA16GC was used for column chromatography. A Shimadzu gas chromatograph / mass spectrometer GC/ MS-QP 2010 with a capillary column RTX-1701 $(60 \mathrm{~m} \times 0.25 \mathrm{~mm} \times 0.25 \mu \mathrm{m}$ film $)$ was used for the separation of anhydrosugars.

\section{Chromatographic separation}

A glass column $(60 \times 2 \mathrm{~cm})$ was filled with a suspension of the resin in a mixture of water and ethanol (4:1). About $1 \mathrm{~g}$ of the pyrolysis

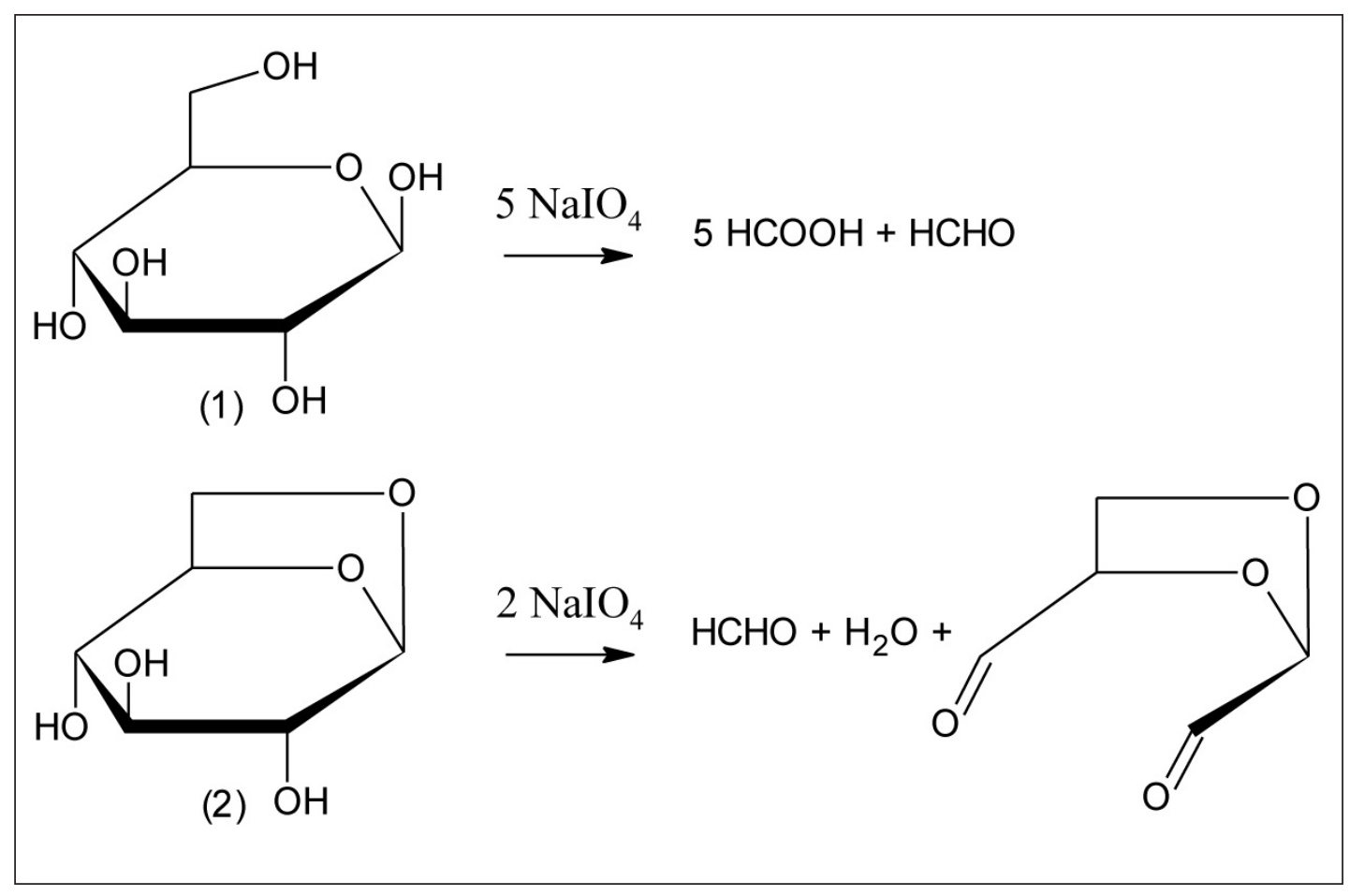

Fig. 1. The periodate oxidation of D-glucose (1) and AGP (2) 
liquid sample was dissolved in $10 \mathrm{~mL}$ of deionized water and filtered through a Whatman 95 filter paper. The filtrate was carried onto the column and separated into fractions. The experiments were performed at room temperature $\left(21 \pm 2{ }^{\circ} \mathrm{C}\right)$, the flow rate was about $1 \mathrm{ml} / \mathrm{min}$.

\section{Iodometric titration}

Two $3 \mathrm{~mL}$ aliquots were taken from each sample into $25 \mathrm{~mL}$ volumetric flasks. One of these was hydrolyzed for $90 \mathrm{~min}$ at $120^{\circ} \mathrm{C}$ in the presence of diluted sulfuric acid (7.5\%). Then both the hydrolyzed and non-hydrolyzed samples were diluted up to $25 \mathrm{~mL}$ with deionized water and $3 \mathrm{~mL}$ of these solutions were oxidized with $1 \mathrm{~mL}$ of $2 \mathrm{M}$ sodium periodate for $4 \mathrm{~h}$ at $40{ }^{\circ} \mathrm{C} \mathrm{pH} 1$. The excess of periodate was masked with $5 \mathrm{~mL}$ of $10 \%$ ammonium molybdate solution. After $15 \mathrm{~min} 1 \mathrm{~mL}$ of glacial acetic acid and $1 \mathrm{~mL}$ of $10 \%$ potassium iodide were added. The samples were titrated with $0.1 \mathrm{M}$ sodium thiosulfate after $15 \mathrm{~min}$, using starch as an indicator. Since AGP and AGF have different reaction stoichiometries with periodate, different equations are to be used to calculate the amount of AGP and AGF:

$$
\begin{aligned}
& n_{\mathrm{AGP}}=\frac{c \cdot\left(V_{\text {after hydrolysis }}-V_{\text {before hydrolysis }}\right)}{18}, \\
& n_{\mathrm{AGF}}=\frac{c \cdot\left(V_{\text {after hydrolysis }}-V_{\text {before hydrolysis }}\right)}{30},
\end{aligned}
$$

where $n$ is the amount of AGP or AGF, $c$ is the molar concentration of sodium thiosulfate, $V$ is the volume of sodium thiosulfate.

\section{GC/MS analysis}

To identify specific anhydrosugars, GC/MS was used with an ion source $250^{\circ} \mathrm{C}$ with electrospray ionization at $70 \mathrm{eV}$. The injector temperature was $250^{\circ} \mathrm{C}$ and the carrier gas was helium at the flow rate $1 \mathrm{~mL} / \mathrm{min}$. The oven program was $1 \mathrm{~min}$ isothermal at $60^{\circ} \mathrm{C}$, then $6 \%$ min up to $270{ }^{\circ} \mathrm{C}$ and finally 10 min at $270^{\circ} \mathrm{C}$. The MS scan range was 15-350. Library MS NIST 147.LI13 was used for compound identification.

\section{RESULTS AND DISCUSSION}

First, a mixture of standard D-glucose and AGP was separated on a WAC exchange column. Afterwards, four samples of pyrolysis liquids were fractionated and analyzed.

\section{Chromatographic separation of an artificial mixture of D-glucose and AGP}

A mixture of standard AGP and D-glucose was separated on a WAC exchange resin column in the $\mathrm{Na}^{+}$form. The flow rate of the eluent was $0.61 \pm 0.07 \mathrm{~mL} / \mathrm{min}$. Figure 2 shows the chromatogram of the standard substances.

The retention times of standard glucose and AGP were $250 \mathrm{~min}$ and $300 \mathrm{~min}$, respectively. The dead time was $80 \mathrm{~min}$. The retention coefficient for glucose was 2.1 and for levoglucosan 2.8. The selectivity coefficient of these two substances was 1.3 and the resolution was 0.65 , which is acceptable for preparative chromatography, but in this case the chromatograms can be used for semi-quantitative characterization of pyrolysis liquids.

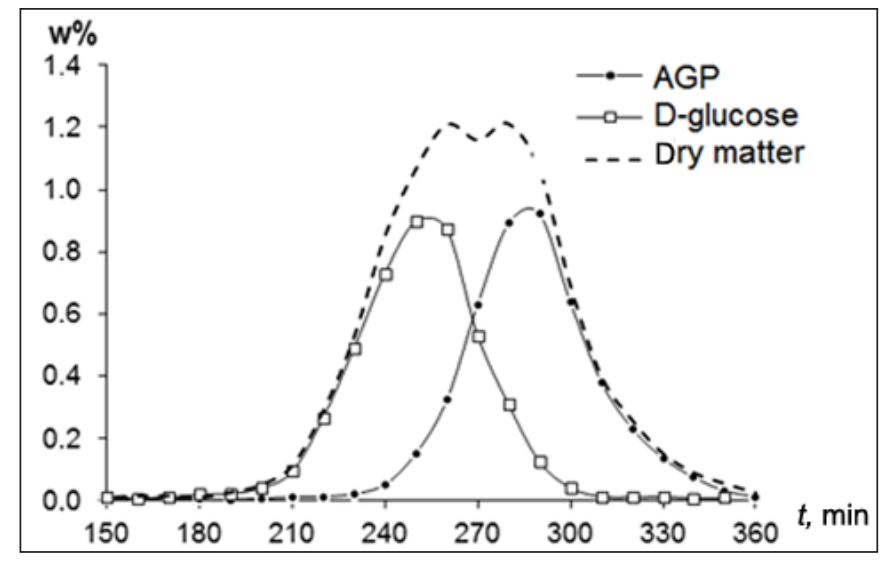

Fig. 2. A chromatogram of standard D-glucose and AGP on a WAC exchange resin column 
Chromatographic separation and analysis of pyrolysis liquid samples

Four real pyrolysis liquid samples were analysed before the chromatographic separation, the results are summarized in Table 1. Figure 3 shows the chromatograms of the four pyrolysis liquid samples. The flow rates of the separations were $1.2 \pm 0.2 \mathrm{~mL} / \mathrm{min}$ for sample 1 , sample 2, sample 3, and $0.85 \pm 0.04 \mathrm{~mL} / \mathrm{min}$ for sample 4.

All four chromatograms show that most sugars are not strongly retained on the column, this means that these sugars are disaccharides or oligosaccharides and that their retention time is determined mostly by size exclusion. Negative sugar values are observed in the sample 1 and sample 2 chromatograms (80-100 $\mathrm{min}$ ), which can be explained by the presence of AGF, which does not react with sodium periodate, thus giving an increased anhydrosugar and decreased sugar result of iodometric titration, if the results are calculated as the amount of AGP. The presence of AGF in the earlier fraction was confirmed by GC/MS analysis. Figure 4 shows a comparison of the mass spectra of the AGF found in the sample and the mass spectra from the data base. Cellobiosan is believed to be present in the first fractions of pyrolysis liquid samples, for example, at 70-80 min of sample 1 , because here again size exclusion mechanisms are at work.

Table 1. Anhydrosugar (expressed as AGP), total sugar and dry matter content in the pyrolysis liquid samples

\begin{tabular}{ccccc}
\hline Sample & w (AGP), $\%$ & w (sugars), $\%$ & w (dry matter), \% \\
\hline 1 & $46.2 \pm 0.5$ & $10.4 \pm 0.2$ & $79.1 \pm 0.4$ \\
\hline 2 & $53.0 \pm 0.4$ & $15.4 \pm 0.2$ & $90.0 \pm 1.1$ \\
\hline 3 & $5.3 \pm 0.07$ & $4.1 \pm 0.03$ & $27.3 \pm 0.9$ \\
\hline 4 & $23.8 \pm 0.3$ & $20.6 \pm 0.2$ & $77.0 \pm 0.2$ \\
\hline
\end{tabular}

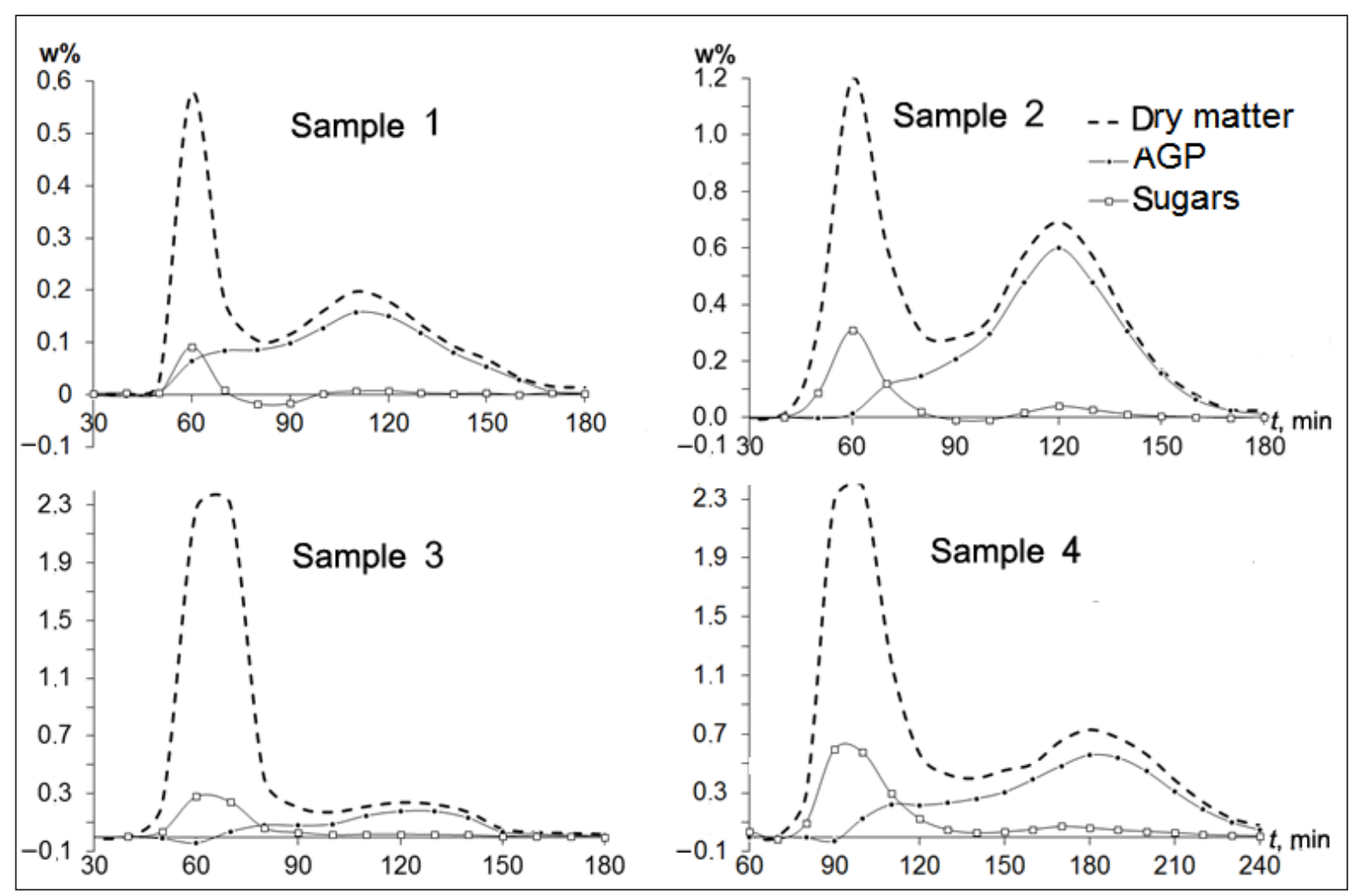

Fig. 3. Chromatograms of pyrolysis liquid samples on a WAC exchange resin column 


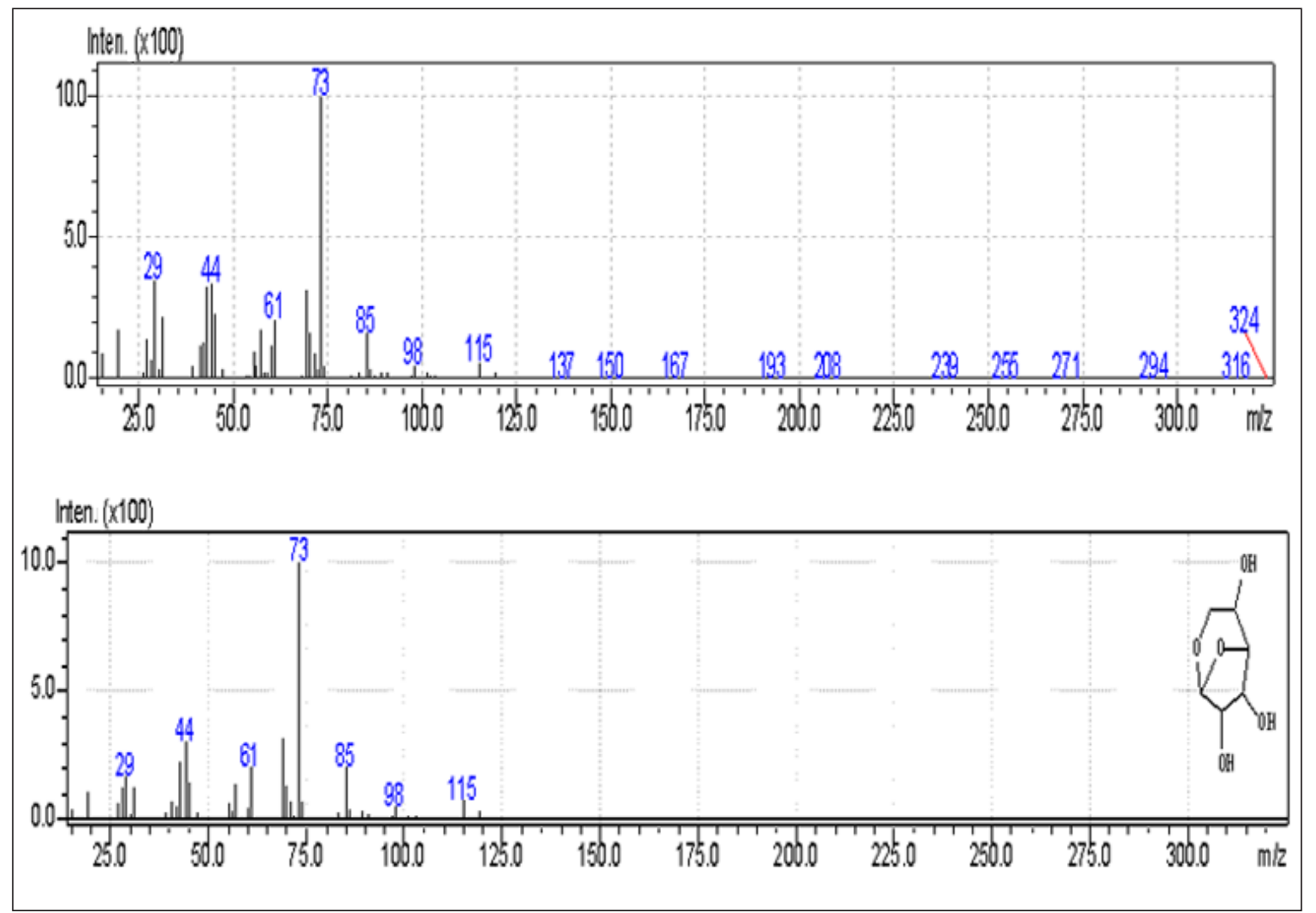

Fig. 4. Mass spectra of AGF found in the sample (above) and the respective mass spectra from the NIST library data base with a $92 \%$ similarity

There is a certain correlation between the sugar / anhydrosugar proportion determined in the samples by the iodometric method before and after sample separation on the ion exchange column. Furthermore, the levoglucosan fraction of the anhydrosugars can be calculated, as shown in Table 2. Although the four samples have different water content and the proportion of sugars and anhydrosugars, the AGP mass fraction of total anhydrosugars is rather similar in all samples - ranging from 67 to $78 \%$, but the mass fraction of AGF is less than $10 \%$.

\section{CONCLUSIONS}

Generally, the iodometric determination of anhydrosugars in fast pyrolysis liquids is a fast and easy method, but sample separation on a WAC exchange column before iodometric titration benefits the characterization of sugar, anhydrosugar and their oligomer content in the sample. The chromatograms of pyrolysis liquid samples depict the proportion of AGP and other anhydrosugars or the total anhydrosugars.

Table 2. Total anhydrosugar (expressed as AGP) mass, AGP mass (according to the chromatographic peak) and the AGP mass fraction of the total anhydrosugars

\begin{tabular}{c|c|c|c}
\hline Sample & $\mathbf{m}$ (total anhydrosugars), $\mathbf{g}$ & $\mathbf{m}(\mathbf{A G P}), \mathbf{g}$ & w (AGP), \% \\
\hline 1 & 0.1334 & $0.0889(100-170 \mathrm{~min})$ & 67 \\
\hline 2 & 0.3623 & $0.2829(110-170 \mathrm{~min})$ & 78 \\
\hline 3 & 0.1142 & $0.0814(110-150 \mathrm{~min})$ & 71 \\
\hline 4 & 0.3640 & $0.2692(160-240 \mathrm{~min})$ & 74 \\
\hline
\end{tabular}




\section{ACKNOWLEDGEMENTS}

The authors gratefully acknowledge the financial support by the Latvian State Research Programme NatRes.

Received 3 July 2014 Accepted 22 September 2014

\section{REFERENCES}

1. Vedernikovs N., Puke M., Kruma I., Brazdausks P. Obtaining of acetic acid from birch wood upon its complex processing. Scientific Journal of Riga Technical University. 2010. Vol. 22. P. 57-63.

2. Leduc S., Lundgren J., Franklin O., Dotzauer E. Location of a biomass based methanol production plant: A dynamic problem in northern Sweden. Applied Energy. 2010. Vol. 87. P. 68-75.

3. Briens C., Piskorz J., Berruti F. Biomass valorization for fuel and chemicals production - a review. International Journal of Chemical Reactor Engineering. 2008. Vol. 6. P. 1-49.

4. Bridgwater A. V. Review of fast pyrolysis of biomass and product upgrading. Biomass Bioenergy. 2012. Vol. 38. P. 68-94.

5. Radlein D. Study of levoglucosan production a review. In: Bridgwater A. V. Fast Pyrolysis of Biomass: A Handbook. Vol. 2. Newbury, 2002. P. 205-243.

6. Patwardhan P. R. Understanding the product distribution from biomass fast pyrolysis. Graduate Thesis and Dissertations. 2010. Paper 11767.

7. De Wild P. J., Reith H., Heerees H. J. Biomass pyrolysis for chemicals. Biofuels. 2012. Vol. 2(2). P. 185-208.

8. Takagaki A., Ebitani K. Glucose to value-added chemicals: Anhydroglucose formation by selective dehydration over solid acid catalysts. Chemistry Letters. 2009. Vol. 38. P. 650-651.

9. Babor K., Kalač V., Tihlaric K. Periodate oxidation of saccharides. III. Comparison of the methods for determining the consumption of sodium periodate and the amount of formic acid formed. Chemical Papers. 1973. Vol. 27(5). P. 676-680.

10. Spince B., Zandersons J., Zhurinsh A. Quantitative analysis of levoglucosan in the presence of glucose and cellobiose using Malaprade reaction and iodometric titration. Proceedings of the 11th European Workshop of Lignocelluloses and Pulp (11th EWLP), August 16-19, 2010, Hamburg, Germany. P. 381-384.

11. Meile K., Zhurinsh A., Spince B. Aspects of periodate oxidation of carbohydrates for the analysis of pyrolysis liquids. Journal of Carbohydrate Chemistry. 2014. Vol. 33(3). P. 105-116.

12. Helle S., Bennet N. M., Lau K., Matsui J. H., Duff S. J. A kinetic model for production of glucose by hydrolysis of levoglucosan and cellobiosan from pyrolysis oil. Carbohydrate Research. 2006. Vol. 342. P. 2365-2370.

13. Saari P., Häkkä K., Jumppanen J., Heikkilä H., Hurme M. Study on industrial scale chromatographic separation methods of galactose from biomass hydrolysates. Chemical Engineering \& Technology. 2010. Vol. 33. P. 137-144.

14. Alexandratos S. D. Ion-Exchange Resins: A Retrospective from Industrial and Engineering Chemistry Research. Industrial \& Engineering Chemistry Research. 2009. Vol. 48(1). P. 388-398.

15. Caruel H., Rigal L., Gaset A. Carbohydrate separation by ligand-exchange liquid chromatography. Correlation between the formation of sugar-cation complexes and the elution order. Journal of Chromatography. 1991. Vol. 558. P. 89104.

\section{K. Meile, A. Zhurinsh, G. Dobele}

\section{ANHIDROCUKRAUS SUDE்TIES PIROLIZĖS SKYSČIUOSE CHARAKTERISTIKA PASITELKIANT KOLONINE CHROMATOGRAFIJĄ BEI JODOMETRINI TITRAVIMĄ}

Santrauka

Celiuliozė ir hemiceliuliozė kartu su ligninu yra pagrindiniai biomasès komponentai, prie kurių taip pat priskiriama ir mediena. Medienos greitos pirolizès metu gaunamas sudètingas produktụ mišinys, iš jo labiausiai paplitę bei vertingiausi komponentai yra cukrus ir anhidrocukrus. Dèl didelio molekulinio svorio junginių mišinyje šiuos cukrų mišinius, esančius pirolizès produktuose, sun$\mathrm{ku}$ analizuoti. Šiame darbe buvo atliktas tyrimas, 
skirtas pagerinti pirolizės skysčiu charakterizavimą, pasitelkus mėginio atskyrimo ant jonų mainų dervos metodą. Siekiant apibūdinti pirolizès skysčius, naudojamas jodometrinio titravimo metodas cukraus ir anhidrocukraus sudèčiai pirolizès skysčiuose su ir be mèginių atskyrimo ant jonų mainų kolonos nustatyti.

Raktažodžiai: jonų mainų dervos, medienos pirolizè, anhidrocukrus, cukrus

К. Майле, А. Журиньш, Г. Добеле

ХАРАКТЕРИСТИКА СОДЕРЖАНИЯ АНГИДРОСАХАРОВ В ПИРОЛИЗНЫХ ЖИДКОСТЯХ ПРИ ПОМОЩИ КОЛОНОЧНОЙ ХРОМАТОГРАФИИ И ЙОДОМЕТРИЧЕСКОГО ТИТРОВАНИЯ

Резюме

Целлюлоза и гемицеллюлозы, наряду с лигнином, являются основными компонентами биомассы, к которой относится идревесина. Поэтому, в результате быстрого пиролиза древесины, получается сложная смесь продуктов, среди которых сахара и ангидросахара являются одними из наиболее распространенных и ценных компонентов. Благодаря наличию высокомолекулярных соединений, оказалось, что такая смесь сахаров продуктов пиролиза трудно поддается анализу. В данной работе проведено исследование с целью улучшения характеристики пиролизных жидкостей посредством разделения образцов на ионообменной смоле. Для характеристики пиролизных жидкостей использовался метод йодометрического титрования с целью определения содержания сахаров и ангидросахаров в пиролизных жидкостях, с и без разделения образцов на ионообменной колонне.

Ключевые слова: ионообменные смолы, пиролиз древесины, ангидросахара, сахар 